\title{
The Impact of Equity Pledge on Investment from the Perspective of Financing Constraints
}

\author{
Jing Zhang \\ School of Economics and Management \\ Beijing Jiaotong University \\ Beijing, China
}

\begin{abstract}
Taking the GEM listed companies in 2014-2018 as the research object; the investment of such enterprises is generally limited by internal cash flow. Then analyzing equity pledge of controlling shareholders in enterprises with financing constraints, there is a positive relationship between the degree of financing constraints and the proportion of equity pledge. Finally, from the perspective of financing constraints, the regression model of equity pledge and investment is constructed. The results find that the behavior of equity pledge triggers short-term market value management and agency problems, which inhibits corporate investment thereby. In small-scale enterprises, most of the pledged funds are used by the controlling shareholders, rather than meeting financing needs. Therefore, the equity pledge increases the financing constraint, resulting in more serious underinvestment.
\end{abstract}

Keywords-equity pledge; corporate investment; financing constraints

\section{INTRODUCTION}

In November 2015, the supply-side reform was initially proposed in China. The early reform aimed at the industry and the goal was to shift from the high-polluting and energyintensive industries to the high-tech-oriented industries. Now, "SSE STAR Market" which is being prepared in 2019 is a supply-side reform of the capital market, supporting emerging high-tech enterprises from the source of funds.

While the policy is beneficial to the development of small and medium-sized high-tech enterprises, it is indispensable to study the survival status of such enterprises. Due to the limited funds available, enterprises are prone to break the capital chain, and external financing has become a widespread financial activity. However, such companies that do business and operate at minimal profits will always face various restrictions. It makes managers feel guilty about introducing foreign capital. Therefore, high-tech SMEs often give up the development of some high-quality products because of insufficient internal funds, that is, they face financing constraints.

The issue of financing constraints has become one of the important bottlenecks restricting the rapid and high-quality development of SMEs. In order to alleviate the restriction of funds, equity pledge is favored by the controlling shareholders of listed companies. Equity pledge is an act of the company's main controlling shareholder to hold the equity owned by the company as collateral to financial institutions and obtain loans. By the end of 2018, the number of markets pledged shares is
634.152 billion shares, accounting for $9.83 \%$ of the total share capital. This paper will focus on the GEM listed companies, which are represented as high-tech industries. Then it explores whether there are widespread financing constraints on such enterprises, and deeply studies the relationship between equity pledge behavior and corporate investment from the perspective of financing constraints.

\section{LITERATURE REVIEW}

\section{A. Financing constraints}

In the perfect capital market, internal and external capital can be replaced by each other. When the company lacks internal funds, it can still freely raise foreign capital. Therefore, corporate investment activities are not affected by financing constraints (Modigliani and Miller, 1958). However, there are so many imperfections in the capital market, which have pushed up the cost of external financing and highlight the cheapness of internal funds. Therefore, the difference between internal and external financing costs is the degree of financing constraints faced by enterprises (Greenwald et.al, 1984). Fazzari, Hubbard, and Peterson (1988) pioneered the FHP theory to combine corporate investment and financing, and constructed an investment-cash flow sensitivity model to measure the financing constraints[1]. At present, there are three characteristic phenomena related to financing constraints.

- Financing constraint influences the company's stocks. Deng Kebin (2014) calculated the WW index as the financing constraint and found that it was positively related to stock returns through the empirical demonstration in A-share listed companies.

- It rules the small-scale effect. Kenneth (2012) introduced the enterprise scale, financial marketization index and capital structure index in the investmentcash flow model. It found that there were financing constraints for small-scale enterprises[2]. Wang Minghu (2015) tested that the scale of the company was negatively correlated with the fluctuation of capital structure, and the financing constraint was positively correlated with the fluctuation of capital structure. Therefore, the expansion of enterprise scale could offset the promotion of financing constraints on capital structure fluctuations[8]. Wien Saidani (2017) added the enterprise scale, enterprise age, Tobin Q, and financial institutional shareholding in the investment- 
cash flow sensitivity model. There were indeed financing constraints in the companies listed on the Tokyo Stock Exchange, and companies with different characteristics brought different levels of financing constraints[3].

- $\quad$ Economic consequences of financing constraints. Liu Shengqiang (2015) empirically examined the negative impact of financing constraints on corporate $R \& D$ investment based on the investment model of Euler's equation[9]. Yan Xiaosheng (2013) used the SA index to measure financing constraints. The conclusion showed that the smoothing effect of working capital on innovation was more prominent in enterprises with severe financing constraints. Xu Shoufu (2016) found that companies with lower financing constraints were more willing to distribute cash dividends, and the level of dividend distribution was higher. Li Wenjing (2017) analyzed that entity companies holding shares in unlisted financial institutions reduced the financing constraints, but the market performance would also decline accordingly.

\section{B. Equity pledge}

The existing literature on equity pledge mainly focuses on two aspects: (1) the motivation for equity pledge, which is divided into good intention motive and malicious motive; (2) the impact on innovation investment, enterprise performance and stock prices, etc.

- Good intention motive, that is, some scholars study whether this external financing method meets the financing needs of enterprises and supports the followup development of enterprises. Zhang Taoyong (2014) analyzed that most of the funds pledged by the controlling shareholders were utilized to meet their own needs[4]. Conversely, Li Wei (2015) found that the external financing of equity pledge satisfied the financing needs of enterprises and enhanced the effect of corporate governance[5].

- The malicious motive, that is, majority shareholders invade the interests of small shareholders. Tan Yan (2013) believed that shareholders who made equity pledges would control the quality of mortgaged equity and that behavior reduced the cavitation of the enterprise. However, Xie Deren (2018) studied that the company which conducted equity pledges had a higher degree of real earnings management than the company that had no pledge of equity, so the former had the motive of the profit invasion[6]. Wang Xiongyuan (2018) proceeded from the perspective of tax avoidance, and the empirical results showed the listed company that the controlling shareholder conducted equity pledge had more tax avoidance in order to curb the risk of control transfer[7].

- Economic consequences of equity pledge, that is, the impact of enterprises' equity pledge on the innovation investment, enterprise performance and stock prices, etc. Some scholars have tested that the controlling shareholder's equity pledge would inhibit corporate innovation investment (Li Changqing, 2018; Wenwen, 2018), and this inhibition was sustainable (Yang Mingjing, 2019). Moreover, controlling shareholder's equity pledge was positively related to company performance (Lin Yan, 2018). After dividing the allocation of the pledged fund, it was found that the performance of the company which used the pledge funds to itself was significantly higher than that whose pledge funds invested by the third party (Zhang Taoyong, 2014). Xie Deren (2016) studied the impact on the company's stock price. The conclusion was that the pledge of equity would trigger the risk of the company's stock price collapse.

\section{THEORETICAL ANALYSIS AND RESEARCH HYPOTHESIS}

Financing constraint is financial reflection at the company level. Equity pledge is the individual behavior of controlling shareholders. Corporate investment is the company's daily activities. This paper first studies the limited situation of corporate investment activities in enterprises with financing constraints. Then it analyzes the behavior of equity pledge by enterprises subject to financing constraint. Finally, it explores the impact of the equity pledge on corporate investment from the perspective of financing constraints.

\section{A. Insufficient investment in enterprises with financing constraints}

The most intuitive manifestation of a company's financing constraint is an insufficient investment. The traditional FHP theory explains this phenomenon under the framework of information asymmetry (As shown in Fig.1).

First, the information asymmetry leads enterprises to prefer the pecking order theory. Since most companies are unable to bear the cost of external fundraising, they are often comfortable with the status quo. They choose to use only internal funds to develop enterprises and give up some high-quality investment projects.

Second, information asymmetry blocks the bank's funding for some SMEs. Facing with excessive financing demands in the financing market, without breaking the central bank's control of interest rates, banks will set non-interest rate loan conditions to eliminate excess demands. This brings high thresholds for credit to enterprises and leads to some of the capital demanders withdraw from the indirect financing market. So enterprises are in a dilemma with limited funding channels.

Third, enterprises have long-term debts. The pressure on repayment has caused corporate managers to be reluctant to raise new funds, which inhabit the investment.

These are the fundamental reasons that make it difficult or even unwilling for financing. Therefore, financing constraints are common in most enterprises.

Research hypothesis 1: GEM listed companies generally have financing constraints, and their investment activities are restricted. 


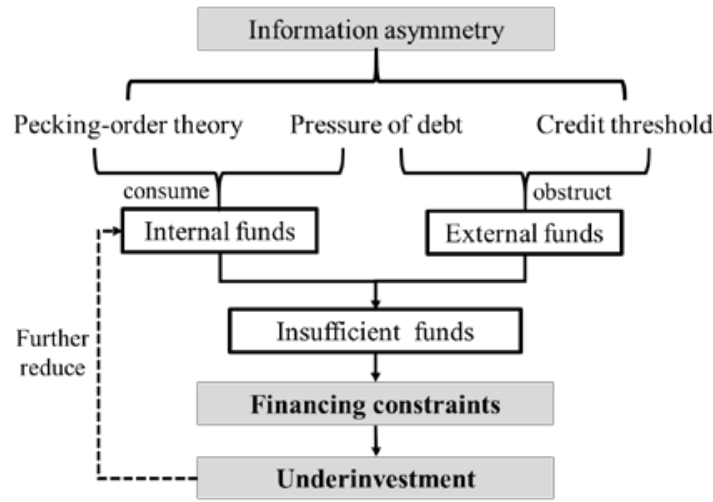

Fig. 1. Insufficient investment caused by financing constraints. (FHP Theory)

\section{B. The behavior of equity pledge by enterprises subject to financing constraint}

The transmission path of financing constraints, when there is a shortage of internal cash flow; external financing can solve the urgent need. The simple approval process for equity pledge has made it a favor of financing decisions (Xie Deren, 2016). Especially in private enterprises, financing constraints are serious, and controlling shareholders are more willing to choose equity pledge in order to obtain funds (Wang Bin[11], 2013). Because the equity pledge has unique flexibility and light assets (Lin Yan, 2018).

For controlling shareholders, equity is a more liquid asset. When a company is located in financial distress, shareholders can pledge their equity to financial institutions for funds. Therefore, enterprises with financing constraints have stronger incentives for controlling shareholders to carry out equity pledge. This paper uses internal cash flow as a measure of financing constraints. When the internal cash flow of the company is small, this company will face the solid financing constraints and the proportion of controlling shareholders' equity pledge will also increase.

Research hypothesis 2: For enterprises with strong financing constraints, the controlling shareholder's equity pledge ratio is relatively high.

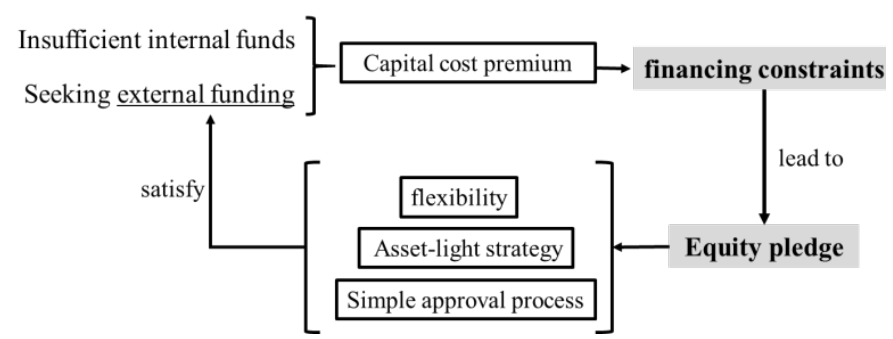

Fig. 2. Equity pledge by enterprises subject to financing constraint

\section{Corporate investment and equity pledge from the perspective of financing constraints}

After the equity pledge, the company is prone to the following three types of problems, which inhabit corporate investment.
Short-term market value management. When controlling shareholders pledge their equity, they convey to the market that the controlling shareholders do not have sufficient funds to compete for control. Once the external agency receives the signal, it will suppress the company's stock. Since the stock price failed to maintain, this company suffers a "burst crisis". The controlling shareholders can only add guarantees or suspend their own cards. Therefore, the controlling shareholders choose to stimulate the stock price to rise in the short term through weakening the corporate investment, because most of investment will be expensed (Li Changqing, 2018). Weakening the investment can reduce costs and improve performance in the short term. This is a means of short-term market value management to make stock prices stable.

Agent conflict. The threshold of equity pledge is low, but pledged funds that it lends are not continuous enough to support long-term investment activities. Therefore, some controlling shareholders do not invest the pledged funds to meet the financing needs of enterprises but choose to use funds for their own or invested in third-party institutions. This "tunneling effect" is the most important reason for restraining corporate investment. Large shareholders pledge their equity in exchange for cash. The conflicts between large and small shareholders in the process of corporate governance will hinder the development of enterprises, and daily activities such as investment are difficult to carry out.

Financing constraints mediating effect. Most of the funds lent from the equity pledge flow to the inside of the enterprise, which is used to upgrade the company value (Zhang Taoyong, 2014). When the performance of the company is good, the external financing constraints will decline. The mitigation of financing constraints is directly reflected in the effective stimulation of corporate investment. However, most controlling shareholders' equity pledge is not for the development of enterprises, but for self-use. This short-selling of funds led to a tightening of internal cash flow and increased financing constraints. Therefore, the phenomenon of insufficient investment will become more obvious.

Research hypothesis 3: Equity pledge has an inhibitory effect on corporate investment.

Research hypothesis 3b: The enterprises which pledged funds almost flow to controlling shareholders or other third parties face have a more serious insufficient investment.

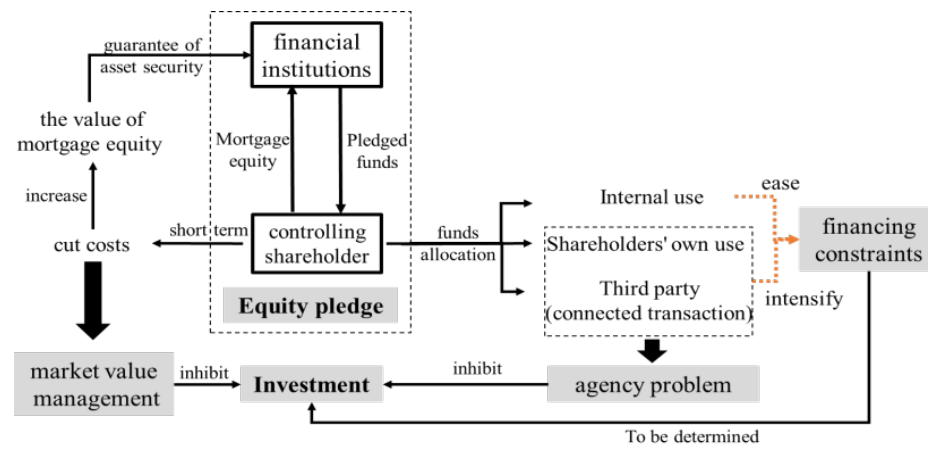

Fig. 3. Equity pledge and investment considering financing constraints 


\section{METHOD}

\section{A. Establishment of the regression equation}

For the research hypothesis 1 , this paper establishes the investment-internal cash flow sensitivity model. There are three categories: the neoclassical model, Tobin q model and sales investment model. However, the capital cost in the neoclassical model is difficult to measure with a single indicator, and multiple indicators are easy to cause a deviation. The calculation of the market capitalization value of the Tobin $\mathrm{q}$ indicator is changing every moment, and the $\mathrm{q}$ value has a measurement error. According to the above analysis, this paper measures the financing constraints by improving the sales investment model derived from Kenneth (2012). As in

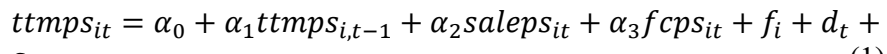

In equation (1), the meanings of the variables are as follows:ttmps $s_{i t}$ : The ratio of the investment expenditure of the enterprise in the $t$ period to the total capital of the current period; saleps $s_{i t}$ : The marginal capital profit of the enterprise; $f c p s_{i t}$ : The ratio of the initial cash flow of the t period and the total capital of the current period; $f_{i}$ : The individual effect of the companies; $d_{t}$ : time effect; $\varepsilon_{i t}$ : a stochastic error.

The degree of investment cash flow sensitivity depends on the coefficient of $f c p s_{i t}$. If $\alpha_{3}>0$ and $\alpha_{3}$ is significant, it indicates that the company's investment is limited by its internal cash flow, that is, the company has financing constraint. The bigger the value is, the greater the degree of financing constraint is. If the company is free to obtain external funds, the parameters of investment and internal cash flow will not be significant.

In view of the research hypothesis 2, this paper uses the internal free cash flow of the enterprise to represent the financing constraint (Wang Minghu[8], 2015), and explores the motives of the controlling shareholder's equity pledge behavior under the constraint of financing. The construction model is as follows:

$$
\begin{aligned}
& \text { pledge_rate } \\
& \varepsilon_{i t}
\end{aligned}=\beta_{0}+\beta_{1} f c p s_{i t}+\sum_{i} \beta_{\mathrm{i}} \mathrm{CONTROL}+f_{i}+d_{t}+
$$

In equation (2), the meanings of the variables are as follows pledge_rate $e_{i t}$ : The proportion of equity pledge of the controlling shareholders; CONTROL: Other variables that affect the internal cash flow of the enterprise (control variables as shown in Table 1).

Whether the equity pledge is higher in enterprises with stronger financing constraint depends on the coefficient of $f c p s_{i t}$. If $\beta_{1}>0$ and $\beta_{1}$ is significant, it indicates that the internal cash flow is significantly negatively correlated with the equity pledge ratio. That is, the lower the internal cash flow, the stronger financing constraints of the enterprise, and the controlling shareholder is more willing to pledge the equity in exchange for funds.
For the research hypothesis 3 , after combining the equation (1) and the equation (2), Investment-equity pledge model under the financing constraint is obtained. Since the enterprise has financing constraints, the financing constraint itself will affect the enterprise investment. Considering the relationship between equity pledge ratio and investment, this paper also introduces the intersection of pledge_rate ${ }_{i t} \times f c p s_{i t}$, the model is established as follows:

ttmps $_{i t}=\gamma_{0}+\gamma_{1}$ pledge_rate r $_{i, t}+\gamma_{2}$ pledge_rate it $\times f c p s_{i t}+$ $\sum_{i} \gamma_{i} \operatorname{CON}+f_{i}+d_{t}+\varepsilon_{i t}$

Equation (3) is the improved investment-equity pledge model. Investment is not limited to the impact of the internal cash flow, but it is limited by the equity pledge behavior of the controlling shareholder. When $\gamma_{1}<0$ and $\gamma_{1}$ is significant, the higher the equity pledge ratio is, the lower the investment activity is, so the equity pledge behavior inhibits the enterprise investment. If $\gamma_{2}$ is significant and $\gamma_{2}>0$, it means that equity pledge exacerbates financing constraints and makes investment more constrained by internal cash.

\section{B. Indicator construction}

The control variables refer to Wang Minghu (2015)[8]. The variables are defined in the following table.

\begin{tabular}{|c|c|c|}
\hline Variable & $\begin{array}{c}\text { Indicator } \\
\text { description }\end{array}$ & Calculation \\
\hline \multirow[b]{2}{*}{$t t m p s_{i, t}$} & $\begin{array}{l}\text { Net cash } \\
\text { flow from }\end{array}$ & Net cash flow from investment \\
\hline & $\begin{array}{l}\text { investment } \\
\text { per share }\end{array}$ & $\overline{\text { Paidin capital at the end of year }}$ \\
\hline \multirow{2}{*}{$\operatorname{fcps}_{i, t}$} & \multirow{2}{*}{$\begin{array}{l}\text { Free cash } \\
\text { flow per } \\
\text { share }\end{array}$} & Free cash flow \\
\hline & & Paidin capital at the end of the period \\
\hline \multirow{2}{*}{ pledge_rate $_{i, t}$} & \multirow{2}{*}{$\begin{array}{c}\text { Equity } \\
\text { pledge ratio }\end{array}$} & Total number of pledged shares \\
\hline & & $\overline{\text { Total share capital at the end of year }}$ \\
\hline \multirow{2}{*}{ leve $_{i, t}$} & \multirow{2}{*}{$\begin{array}{l}\text { Total debt } \\
\text { ratio }\end{array}$} & Total liabilities \\
\hline & & Total asset \\
\hline $\operatorname{size}_{i, t}$ & $\begin{array}{l}\text { Business } \\
\text { scale }\end{array}$ & Natural logarithm of total assets \\
\hline block $_{i, t}$ & $\begin{array}{c}\text { Equity } \\
\text { concentratio } \\
n\end{array}$ & $\begin{array}{l}\text { First controlling shareholder's } \\
\text { shareholding ratio }\end{array}$ \\
\hline \multirow{2}{*}{$\boldsymbol{r o e}_{i, t}$} & \multirow{2}{*}{ Roe } & Net profit after tax \\
\hline & & $\overline{\text { Net assets at the end of year }}$ \\
\hline \multirow{2}{*}{ sales $_{i, t}$} & \multirow{2}{*}{$\begin{array}{c}\text { Total } \\
\text { operating } \\
\text { income per } \\
\text { share }\end{array}$} & Total operating income \\
\hline & & $\overline{\text { Paidin capital at the end of year }}$ \\
\hline
\end{tabular}

TABLE I. VARIABLE DEFINITIONS

\section{Sample selection and descriptive statistics}

This paper selects the financial data of the GEM listed companies from 2014 to 2018. All data come from the WIND database. In order to ensure the comparability and completeness of the data, this paper excludes companies whose time series data is incomplete and controls the types of enterprises through excluding central state-owned enterprises, regional state-owned enterprises, public enterprises, foreign- 
funded enterprises. Finally, this paper selected 352 private enterprises for research.

Considering that different scales have an influence on internal cash flow, this paper constructs the coefficient of variation to compartmentalize scales. The coefficient of variation, which is calculated based on the average and standard deviation, is an indicator to represent a dynamic of firm size.

$$
C V_{\text {size }}=\frac{\operatorname{stdev}(\ln (\text { total asset }))}{\text { average }(\text { ln }(\text { total asset }))}
$$

$C V_{\text {size }}$ is small, indicating that the enterprises have large total assets in the past five years and the total assets remain at a high level with minimal change. Such enterprises are divided into large-scale enterprises. Based on the classification of $C V_{\text {size }}$, the full sample is divided into three categories: largescale group, medium-scale group and small-scale group. Each group has 117 companies. In addition to making empirical analysis on the full sample, this paper also carries out model tests on three sample groups in different scales.

The descriptive statistics of explanatory variables, interpreted variables and control variables in the empirical model are shown in Table 2. According to mean, Small-scale enterprises have the least investment activities, but the average value of equity pledges is the highest.

TABLE II. DESCRIPTIVE STATISTICS OF VARIABLES

\begin{tabular}{|c|c|c|c|c|c|c|c|c|}
\hline \multicolumn{2}{|c|}{ Types } & ttmps & pledge_rate & fcps & sales & level & block & roe \\
\hline \multirow{4}{*}{ Full } & Mean & -0.57 & 0.16 & -0.07 & 3.90 & 0.33 & 0.30 & -0.02 \\
\cline { 2 - 9 } & Med & -0.37 & 0.11 & 0.09 & 2.23 & 0.31 & 0.28 & 0.07 \\
\cline { 2 - 9 } & Max & 4.94 & 1.41 & 13.5 & 603.6 & 1.69 & 0.65 & 0.45 \\
\cline { 2 - 9 } & Min & -7.30 & 0.00 & -7.15 & 0.04 & 0.01 & 0.07 & -20.9 \\
\hline \multirow{5}{*}{ Small } & Mean & -0.75 & 0.19 & -0.20 & 5.83 & -0.20 & 0.30 & -0.05 \\
\cline { 2 - 9 } & Med & -0.58 & 0.15 & 0.03 & 2.77 & 0.04 & 0.29 & 0.08 \\
\cline { 2 - 9 } & Max & 4.94 & 1.21 & 13.5 & 603.6 & 13.5 & 0.65 & 0.32 \\
\cline { 2 - 9 } & Min & -5.98 & 0.00 & -6.16 & 0.04 & -6.16 & 0.07 & -20.9 \\
\hline \multirow{5}{*}{ large } & Mean & -0.58 & 0.16 & -0.07 & 3.09 & 0.33 & 0.29 & -0.04 \\
\cline { 2 - 9 } & Med & -0.36 & 0.11 & 0.10 & 2.23 & 0.31 & 0.27 & 0.06 \\
\cline { 2 - 9 } & Max & 1.84 & 1.41 & 3.30 & 22.49 & 1.69 & 0.63 & 0.45 \\
\cline { 2 - 9 } & Min & -7.31 & 0.00 & -6.99 & 0.05 & 0.03 & 0.07 & -20.9 \\
\cline { 2 - 9 } & Mean & -0.38 & 0.13 & 0.05 & 2.77 & 0.28 & 0.31 & 0.04 \\
\cline { 2 - 9 } & Med & -0.26 & 0.08 & 0.11 & 1.91 & 0.26 & 0.29 & 0.07 \\
\cline { 2 - 9 } & Max & 2.54 & 1.35 & 2.73 & 27.38 & 0.89 & 0.64 & 0.42 \\
\cline { 2 - 9 } & Min & -5.08 & 0.00 & -7.15 & 0.14 & 0.01 & 0.07 & -5.06 \\
\hline \multirow{4}{*}{} & & & & & & &
\end{tabular}

\section{EMPIRICAL RESULTS AND ANALYSIS}

\section{A. Investment activities are restricted in GEM listed companies}

An empirical study of the regression equation (1), the results are shown in Table 3 . In the full sample (column 1 in Table 3), the coefficients of variables are significant at the $95 \%$ confidence level. The p-value of $f c p s_{i, t}$ is lower than 0.0010 , and rejects the null hypothesis that the parameter is 0 . So the investment is sensitive to internal cash flow. It means that the internal free cash flow is insufficient to support the corporate investment, which forces enterprises to choose external financing. But the existence of information asymmetry pushes up the integration of external funds and in turn affects the financing capability of enterprises. That is, GEM listed companies do face financing constraints.

As shown in columns 2, 3 and 4, companies of different sizes face different levels of financing constraints. For smallscale enterprises, the coefficient before $f c p s_{i, t}$ is significant at the $99 \%$ confidence level and the value is 0.0865 , which is higher than the full sample of 0.0664 . It means that small-scale enterprises have stronger financing constraints and corporate investment is more restricted. The coefficient before $f c p s_{i, t}$ in the medium-scale enterprises is significant at the $95 \%$ confidence level. The value is 0.0804 , which is lower than small-scale enterprises. So medium-scale enterprises have financing constraints too, but the degree of limitation on corporate investment of such enterprises is less than that of small-scale enterprises. The coefficient of $f c p s_{i, t}$ is not significant in large-scale companies and investments in such enterprises are not limited to internal funds. Most large enterprises have many external financing channels. Therefore, the cost of obtaining external funds in the capital market is much lower than SMEs.

TABLE III. LIMITED INVESTMENT OF ENTERPRISES FROM THE PERSPECTIVE OF FINANCING CONSTRAINTS

\begin{tabular}{|c|c|c|c|c|}
\hline Variables & Full sample & Small-scale & Medium-scale & Large-scale \\
\hline \multirow{2}{*}{$\boldsymbol{f c p s}_{\boldsymbol{i}, \boldsymbol{t}}$} & $0.0664^{* * *}$ & $0.0865^{* * *}$ & $0.0804^{* *}$ & -0.0833 \\
\cline { 2 - 5 } & $(3.3836)$ & $(3.1461)$ & $(2.2029)$ & $(-1.4623)$ \\
\hline \multirow{2}{*}{$\boldsymbol{t t m p s}_{\boldsymbol{i}, \boldsymbol{t}-\mathbf{1}}$} & $-0.2155^{* * *}$ & $-0.3186^{* * *}$ & $-0.1556^{* * *}$ & $-0.1892^{* * *}$ \\
\cline { 2 - 5 } & $(-7.6779)$ & $(-6.1261)$ & $(-3.4615)$ & $(-4.1655)$ \\
\hline \multirow{2}{*}{ salesps $_{\boldsymbol{i}, \boldsymbol{t}}$} & $0.0049^{* * *}$ & $0.0060^{* * *}$ & $-0.1633^{* * *}$ & -0.0277 \\
\cline { 2 - 5 } & $(2.5949)$ & $(2.8112)$ & $(-5.412)$ & $(-1.0438)$ \\
\hline \multirow{2}{*}{ cons } & $-0.7111^{* * *}$ & $-1.0750^{* * *}$ & -0.1388 & $-0.3481^{* * *}$ \\
\cline { 2 - 5 } & $(-26.7578)$ & $(-18.6072)$ & $(-1.4259)$ & $(-4.6515)$ \\
\hline \multirow{2}{*}{ obs } & 1408 & 472 & 468 & 468 \\
\hline
\end{tabular}

\section{B. Equity pledge from the perspective of financing constraints}

The data are brought into the regression equation (2), and the empirical results are shown in Table 4. In the full sample, the coefficient of the main explanatory variable $f c p s_{i, t}$ is negative and significant at the $99 \%$ confidence level. When there is less internal cash flow, these companies face serious financing constraints, which force the controlling shareholders to carry out equity pledge from the external capital market. Research hypothesis 2 is verified.

In small-scale group, the coefficient of $f c p s_{i, t}$ is significant at the $90 \%$ confidence level, so the increase in the equity pledge ratio is indeed affected by the shortage of internal cash flow. The value is 0.0097 , which is the smallest in all types of 
enterprises. That is to say. The equity pledge of the controlling shareholders in a small-scale enterprise is rarely caused by insufficient internal cash flow. Most of them pledge their shares to exchange funds for their own use. Large shareholders' invasions of profit are more likely to occur in such enterprises. For medium-scale group, the parameter is significant at the $95 \%$ confidence level and the value is 0.0183 , which is bigger than the full sample and the small-scale sample. As for large-scale enterprises, the coefficient is 0.0535 , which is significant at the $99 \%$ confidence level. Due to the cautiousness of the controlling shareholders in the latter two groups, the occurrence of equity pledge is more likely happened due to the insufficient internal cash flow. In medium-scale enterprises and the large-scale enterprises, the controlling shareholders have incentives to pledge equity for funds to develop projects.

TABLE IV. EQUITY PLEDGE FROM THE PERSPECTIVE OF FINANCING CONSTRAINTS

\begin{tabular}{|c|c|c|c|c|}
\hline Variables & full sample & Small-scale & Medium-scale & Large-scale \\
\hline \multirow{2}{*}{ fcps $_{i, t}$} & $-0.0141^{* * *}$ & $-0.0097^{*}$ & $-0.0183^{* *}$ & $-0.0535^{* * *}$ \\
\cline { 2 - 5 } & $(-3.5100)$ & $(-1.7814)$ & $(-2.5243)$ & $(-4.1840)$ \\
\hline \multirow{2}{*}{ leve $_{i, t-1}$} & $-0.1216^{* *}$ & -0.1242 & $-0.1965^{* *}$ & $-0.1940^{*}$ \\
\cline { 2 - 5 } & $(-2.4240)$ & $(-1.5347)$ & $(-2.3349)$ & $(-1.9343)$ \\
\hline \multirow{2}{*}{ block $_{i, t}$} & $0.4769^{* * *}$ & $0.8089^{* * *}$ & 0.0529 & 0.3915 \\
\cline { 2 - 5 } & $(3.9560)$ & $(4.1634)$ & $(0.2887)$ & $(1.4304)$ \\
\hline \multirow{2}{*}{ roe $_{i, t}$} & 0.0027 & $0.0100^{*}$ & $-0.0132^{* *}$ & $0.0579^{* * *}$ \\
\cline { 2 - 5 } & $(0.6624)$ & $(1.7398)$ & $(-2.1137)$ & $(2.7159)$ \\
\hline \multirow{2}{*}{ salesps $_{i, t}$} & 0.0003 & 0.0001 & $0.0275^{* * *}$ & $0.0155^{* * *}$ \\
\cline { 2 - 5 } & $(0.7113)$ & $(0.2518)$ & $(4.5846)$ & $(2.6877)$ \\
\hline \multirow{2}{*}{ cons $^{*}$} & 0.0607 & 0.0011 & $0.1235^{* *}$ & 0.0343 \\
\cline { 2 - 5 } & $(1.5362)$ & $(0.0168)$ & $(2.0798)$ & $(0.3890)$ \\
\hline
\end{tabular}

\section{Equity pledge and investment considering financing constraints}

According to Table 3, this paper only introduces the cross term of pledge_rate $e_{i t} \times f c p s_{i t}$ in small-scale group and medium-scale group, which have proved with financing constraints. The regression results of equation(3) are given in Table 5. The coefficient before pledge_rate ${ }_{i, t}$ is negative and significant at the $99 \%$ confidence level, indicating that the higher the equity pledge ratio is, the less the enterprise investment is. The coefficient of pledge_rate ${ }_{i t} \times f c p s_{i t}$ is positive and significant at the $95 \%$ confidence level. This shows that the equity pledge will aggravate the financing constraints faced by enterprises, which will further lead to insufficient investment. Research hypothesis 3 was verified.

The relationship between equity pledge and investment is quite distinct in different firm sizes. The coefficient of pledge_rate $e_{i, t}$ in small-scale enterprises is -1.1669 and its absolute value is the largest one comparing other groups. It means that equity pledge in a small enterprise has the strongest inhibitory effect on investment. The coefficient of pledge_rate ${ }_{i t} \times f c p s_{i t}$ is 0.1197 , which is also larger than the other groups. It indicates that after the controlling shareholders' equity pledge, financing constraints in small companies will be deepened and lead to a more serious extent of insufficient investment.

In order to understand the reason that equity pledge brings constraints on investment, this paper analyzes the allocation of pledged funds in small-scale enterprises. According to Figure 4, about $41.26 \%$ of the companies that the pledged funds flow to shareholders own use are small-scale. That is, this kind of interest encroachment is more likely to occur in small-scale enterprises. After all, the uncertainty of development has caused shareholders in small enterprises to face losses at any time. In order to protect themselves, major shareholders can only exchange funds through equity pledge which is lowthreshold. But shareholders with low shareholdings cannot obtain funds through this channel. The problem of proxy conflicts appears. When the controlling shareholders need continuous pledges to encroach on their interests, they have to carry out short-term market value management. In summary, it is inevitable that corporate investment will be suppressed.

TABLE V. EQUITY PLEDGE AND INVESTMENT CONSIDERING FINANCING CONSTRAINTS

\begin{tabular}{|c|c|c|c|c|}
\hline Variables & $\begin{array}{c}\text { full } \\
\text { sample }\end{array}$ & $\begin{array}{c}\text { Small- } \\
\text { scale }\end{array}$ & $\begin{array}{l}\text { Medium- } \\
\text { scale }\end{array}$ & Large-scale \\
\hline \multirow{2}{*}{ pledge_rate $_{i, t}$} & $-0.4896^{* * *}$ & $-1.1669^{* * *}$ & -0.2460 & -0.1714 \\
\hline & $(-3.1282)$ & $(-4.1967)$ & $(-0.8598)$ & $(-0.7321)$ \\
\hline \multirow{2}{*}{$\begin{array}{l}\text { pledge_rate }_{i, t} \\
\times f c p s_{i, t}\end{array}$} & $0.1160^{* *}$ & $0.1197^{* *}$ & 0.0702 & \multirow{2}{*}{ - } \\
\hline & $(2.5705)$ & $(2.1746)$ & $(0.4522)$ & \\
\hline \multirow{2}{*}{$t t m p s_{i, t-1}$} & $-0.2280^{* * * *}$ & $-0.2968^{* * *}$ & $-0.1568^{* * *}$ & $-0.2673^{* * *}$ \\
\hline & $(-8.3133)$ & $(-5.770)$ & $(-3.4551)$ & $(-6.0549)$ \\
\hline \multirow{2}{*}{ salesps $_{i, t}$} & $0.0041^{* *}$ & $0.0061^{* * *}$ & $-0.1545^{* * *}$ & -0.0271 \\
\hline & (2.2083) & (2.9293) & $(-4.9167)$ & $(-1.0795)$ \\
\hline \multirow{2}{*}{$\operatorname{leve}_{i, t}$} & -0.2600 & 0.6481 & 0.3669 & $-0.8630^{* *}$ \\
\hline & $(-1.0435)$ & $(1.5531)$ & (0.9671) & $(-1.9008)$ \\
\hline \multirow{2}{*}{ block $_{i, t}$} & $1.9819^{* * * *}$ & $2.1795^{* *}$ & -1.1361 & $3.8710^{* * *}$ \\
\hline & (2.8790) & (2.1126) & $(-1.1844)$ & (2.9298) \\
\hline \multirow{2}{*}{$\boldsymbol{r o e}_{i, t}$} & -0.0174 & -0.0275 & 0.0180 & -0.0215 \\
\hline & $(-0.8648)$ & $(-0.9027)$ & (0.5535) & $(-0.2293)$ \\
\hline \multirow{2}{*}{ _cons } & $-1.1285^{* * *}$ & $-1.7337^{* * *}$ & 0.0684 & $-1.2856^{* * *}$ \\
\hline & $(-5.2861)$ & $(-4.7684)$ & $(0.2171)$ & $(-3.1235)$ \\
\hline
\end{tabular}

Note: Where*** means $\mathrm{p}<0.01$, ** means $\mathrm{p}<0.05$, * means $\mathrm{p}<0.1$

However, the coefficients of the two main explanatory variables are not significant in the medium-scale group. While the significant variable is salesps $s_{i, t}$, the investment of medium-sized enterprises depends more on the sales revenue (column 3 of Table 5). Figure 4 shows that about $33.57 \%$ of the enterprises that use the pledged funds for shareholders themselves are medium-sized and about $33.66 \%$ of the enterprises which pledged funds flow into internal are mediumsized too. Therefore, whether the equity pledge intensifies or mitigates financing constraints has not been determined in this group. The coefficient of pledge_rate ${ }_{i t} \times f c p s_{i t}$ is not significant. 

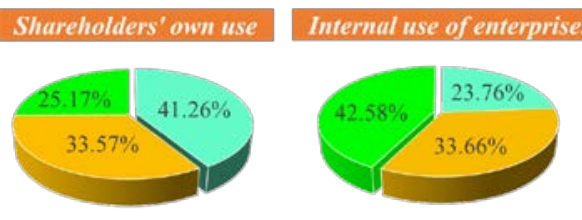

$\square$ small

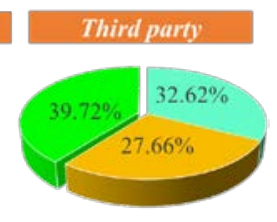

large

Fig. 4. Distribution of pledged funds

About $42.58 \%$ of enterprises with raising the pledged funds for internal use are large-scale (figure 4). It can be seen that large-scale enterprises are more willing to carry out the behavior of equity pledge to develop listed companies. When the company develops to a certain scale, the internal business is basically stable. After the controlling shareholder pledges the stock, the stock price will not fall sharply because of this individual behavior. There is no need for shareholders to cut investment in order to control stock prices in the short term. So the coefficient before pledge_rate $e_{i, t}$ is not significant. In large-scale group, the significant variables at $95 \%$ confidence level are block $_{i, t}$ and leve $_{i, t}$ (column 4 of Table 5). Due to the wide range of financing channels, the investment of large-scale enterprises is relying on long-term equity changes. Therefore, the complex capital structure has become the main factor affecting corporate investment.

\section{CONCLUSION}

From the perspective of financing constraints, this paper first explores the status quo of limited investment and then explores the motives of controlling shareholders' equity pledge. Finally, it tests the relationship between equity pledge and investment. Results are as follows:

1) There are widespread financing constraints in the GEM listed companies.

2) In SMEs, investment is limited by internal cash flow. But corporate investment has no significant relationship with internal funds in large-scale companies, that is, they face no financing constraint.

3) When internal funds are small, the financing constraints are strong. So the controlling shareholders are more willing to external financing, and the equity pledge ratio is also higher.

4) In small-scale enterprises, the equity pledge of the controlling shareholders is rarely caused by insufficient internal cash flow. In medium-scale enterprises and the large-scale enterprises, the controlling shareholders have incentives to pledge equity for funds to make up for the lack of internal funds.

5) In the full sample and small-scale sample, the behavior of the controlling shareholders' equity pledge brings market value management and agency problems, which in turn inhibits corporate investment. What's more, it will lead to a deeper financing constraint and a serious insufficient investment. The reason is that most of the pledged funds are used by controlling shareholders themselves, rather than used to meet financing needs.

6) However, the intensification or mitigation of the financing constraints caused by controlling shareholders' equity pledge has not been determined in medium-scale enterprises. So the inhibition of equity pledge on investment is not significant. The investment of large-scale enterprises is relying on long-term equity changes not short-term equity changes like equity pledge.

\section{REFERENCES}

[1] Fazzari, Steven, Hubbard, R. Glenn and Petersen, Bruce, (1988), Financing Constraints and Corporate Investment, Brookings Papers on Economic Activity, 19, issue 1, p. 141-206.

[2] Kenneth S. Chan, Vinh Q.T. Dang, Isabel K.M. Yan, Financial reform and financing constraints: Some evidence from listed Chinese firms, In China Economic Review, Volume 23, Issue 2, 2012, Pages 482-497, ISSN 1043-951X

[3] Wien Saidani, Badreddine Msolli, Aymen Ajina, Research and development investment and financing constraints: The case of Japan, In Research in International Business and Finance, Volume 42, 2017, Pages 1336-1342, ISSN 0275-5319.

[4] Zhang Taoyong, Chen Yanhua. Equity Pledge, Capital Investment and Company Performance-Based on Empirical Data of Equity Pledge of Controlling Shareholders of Listed Companies in China[J].Journal of Nanjing Audit University, 2014, 11(06):63-70. (In Chinese)

[5] Li Wei, Zheng Guojian. The controlling shareholder's equity pledge financing and interest encroachment under the motive of market value management[J]. Accounting Research, 2015(05): 42-49+94. (In Chinese)

[6] Xie Deren, Liao Wei. Equity Pledge of Controlling Shareholders and Real Earnings Management of Listed Companies[J]. Accounting Research, 2018(08): 21-27. (In Chinese)

[7] Wang Xiongyuan, Ouyang Caiyue, Shi Zhenyang. Equity Pledge, Control Transfer Risk and Tax Avoidance[J]. Economic Research, 2018, 53(01): 138-152. (In Chinese)

[8] Wang Minghu, Wang Xiaowei.Enterprise Size, Financing Constraints and Capital Structure Fluctuations[J].Journal of Nanjing Audit University, 2015, 12(02):12-18. (In Chinese)

[9] Liu Shengqiang, Lin Zhijun, Sun Fangcheng, Chen Hanwen. The Impact of Financing Constraints and Agency Costs on Corporate R\&D Investment-Based on Empirical Evidence of Listed Companies in China[J].Accounting Research, 2015(11):62-68+97. (In Chinese)

[10] Wang Bin, Cai Anhui, Feng Yang.Equity Pledge of Large Shareholders, Risk of Control Transfer and Company Performance[J].Systems Engineering Theory and Practice, 2013, 33(07):1762-1773. (In Chinese) 